\title{
Santa Fe centre seeks second wind
}

[SANTA FE] The Santa Fe Institute (SFI) in New Mexico was set up to escape from US funding restrictions, turf wars, internal division and isolation from the outside world. Those were among the factors that drove a small cadre of talented physicists from the Los Alamos National Laboratory in New Mexico in 1984. But 13 years on, and the institute is having to wrestle with some of the problems its founders wished to leave behind.

The pioneers dreamed of creating a unique, multidisciplinary environment that would nurture their new science of complexity in the picturesque artists' playground of Santa Fe - preferably supported by a healthy endowment of several hundred million dollars.

The institute has struggled to build a substantial endowment, and recently lost a major channel of funding from the Defense Advanced Research Projects Agency (DARPA). But most important, according to its new management team, Santa Fe must now fight to maintain the very fluidity and sense of excitement that was supposed to differentiate it from a university or government laboratory.

Complexity theory holds that both natural and man-made systems can be most effectively modelled as a complex, adaptive system, whose sum is of far greater sophistication than its component parts. In applications ranging from economics to atmospheric science, it seeks to replace the old deterministic models, based on Newtonian physics, with new adaptive ones more akin to molecular biology.

\section{Values}

The institute has half-a-dozen resident faculty and 30 visiting scientists at any one time, and the quality of their work is not in any doubt. As just one example, the seminal paper on the fast replication of the HIV virus in the human body, published by a team led by researchers from the Aaron Diamond AIDS Research Center in New York (Nature 373, 123; 1995), was coauthored by two visitors to Santa $\mathrm{Fe}$ - Avidan Neumann and Alan Perelson. But the institute still struggles to convince outsiders of the universal value of its approach.

"We've heard a number of complaints about the institute and how it had changed direction," says Ellen Goldberg, former associate provost for research at the University of New Mexico, who arrived as president of the institute eighteen months ago. Goldberg says there have been complaints "that we're losing our interdisciplinary nature, that we're not looking forward, and not identifying what we mean by excellence".

Goldberg and Erica Jen, a mathematician from Los Alamos who arrived at SFI a year ago as vice-president, called in an independent review panel to ask some tough questions about the institute's structure. The panel - chaired by two members of SFI's external science board, Simon Levin of Princeton University and Henry Wright of the University of Michigan — was asked, for example, if there should be faster turnover of the small core of resident researchers. It was asked how best to re-establish what Jen terms the "greater propensity for cross-disciplinary discussion of fundamental intellectual themes" in SFI's early years.

The panel was also asked how the institute should measure its own performance. "We have never really looked at this," explains Goldberg. "But we're no longer in our infancy. We are an institute coming of age and we need to ask ourselves these kinds of questions."

Goldberg, an immunologist who brings to SFI a disarming frankness about the task in hand as well as a powerful track record of

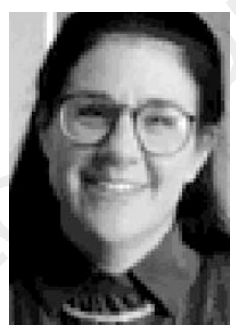

Goldberg: longterm plans. building up research at University of New Mexico, says the funding situation is stable at around $\$ 5$ million a year, despite the recent termination of an arrangement with DARPA that could have brought in as much as $\$ 2$ million a year.

When a new institute is born, she says, "there is a lot of excitement but no money. In the second phase, there is a lot of money but not so much excitement. We got a reputation as being flaky. I think the institute felt it was above telling people what was coming out of its work, and that was wrong."

Goldberg is raising money for the expansion of SFI's premises in the hills above Santa $\mathrm{Fe}$, to boost its capacity to 50 researchers at a time. Her aim is to raise the $\$ 8$ million needed by January 1999 and then spend five years building an endowment — "I'd love it to be \$50 million" - that will support perhaps half the institute's research.

Jen, who managed high-performance computer research at Los Alamos and has been associated with SFI for ten years, says, "A lot of extremely good scientists may have been put off from coming here by the perception that the Santa $\mathrm{Fe}$ Institute is trying to develop a theory of everything." She sees the institute's strength as formulating questions and generating new ideas - not problem-solving. "We haven't made it clear that we are a fundamental research institute looking at general principles," she says.

SFI withdrew from the \$2-million DARPA arrangement, Jen says, after new programme managers at the agency asked it to deliver applied complexity research for military purposes. DARPA support may continue at $\$ 750,000$ a year.

Jen identifies Santa Fe's most difficult challenge as maintaining a flow of new ideas. "The question is how do you encourage turnover and maintain fluxes of new people and new ideas," she says. "Even very smart people will start running out of new ideas at some point."

The review panel, whose report was circulated at Santa Fe last week, recommends that faculty be appointed for two years initially, with a possibile three- or fouryear extension, and that the institute should "avoid defacto tenure positions".

\section{Appointments}

The institute faces difficult choices about resident appointments in the coming year. Three of the six resident professors Nobel prizewinning physicist Murray GellMann, biologist Stuart Kauffman and economist Brian Arthur - have five-year contracts which expire in 1998. Goldberg skirts around the question of whether any of these SFI stalwarts might be encouraged to move on. "These are the kind of questions we'd have to ask ourselves," she says. Renewals are made by the SFI trustees, subject to Goldberg's recommendation. "It has to be done very thoughtfully," she says.

Kauffman, who gave up tenure at the University of Pennsylvania to join SFI, is indignant at the idea that faculty must be rotated to generate new ideas. "The pot is pretty well stirred now," he says, citing the fact that he is publishing economics research "which I was just talking to Newt Gingrich about this afternoon". As well as the Speaker of the House of Representatives, Vice-President Al Gore has shown personal interest in Kauffman's work, which explains economic growth in ecological terms.

He believes the institute needs long-term appointments to strengthen its institutional memory and to enable faculty to apply for regular grants from funding agencies. "I know in my body something I believe that this institute is about, which I changed my life for," he says.

Gell-Mann says cross-disciplinary research is working as well as ever, but problems arise in communications between different interdisciplinary groups. "There seems to be some sentiment against retaining the category of professors," he says, referring to the researchers who stay at SFI for five-year terms. "I don't see why anyone would be against that: it seems to me it's useful to have some institutional memory."

Gell-Mann remains puzzled that US philanthropists have not backed SFI with 
the large endowment the founders hoped for in the early days, when they planned a different sort of institute with a large permanent faculty. "If I were wealthy, I'd want to give my money to something new, challenging and exciting - something like the Santa Fe Institute." But he thinks things are improving on the money-raising front: "Ellen is a fireball."

John Casti, a visiting member of faculty from the Technical University of Vienna in Austria and editor of Complexity, the house journal, says that although opinion is divided over the question of resident faculty, there is no fierce in-fighting.

Casti looks at the Institute for Advanced Study in Princeton, New Jersey — which has hired permanent faculty of exceptional ability but has arguably failed in crossdisciplinary research - as an example of how "empire-building" sets in when positions are assured for life.

The new management team at Santa Fe thinks the institute needs to shed its reputation for arrogance and reach out to a wider scientific community. But, as Casti points out, the arrogance may be implicit in Santa Fe's novel approach to scientific enquiry. "This institute has gotten a lot of heat from people who say that what we're doing is not really science," he says. "The Santa Fe Institute is pushing a brand of intellectual medicine that is by no means universally accepted. People here have to be real risktakers - people with monumental selfconfidence who don't care what anyone else says."

ColinMacilwain

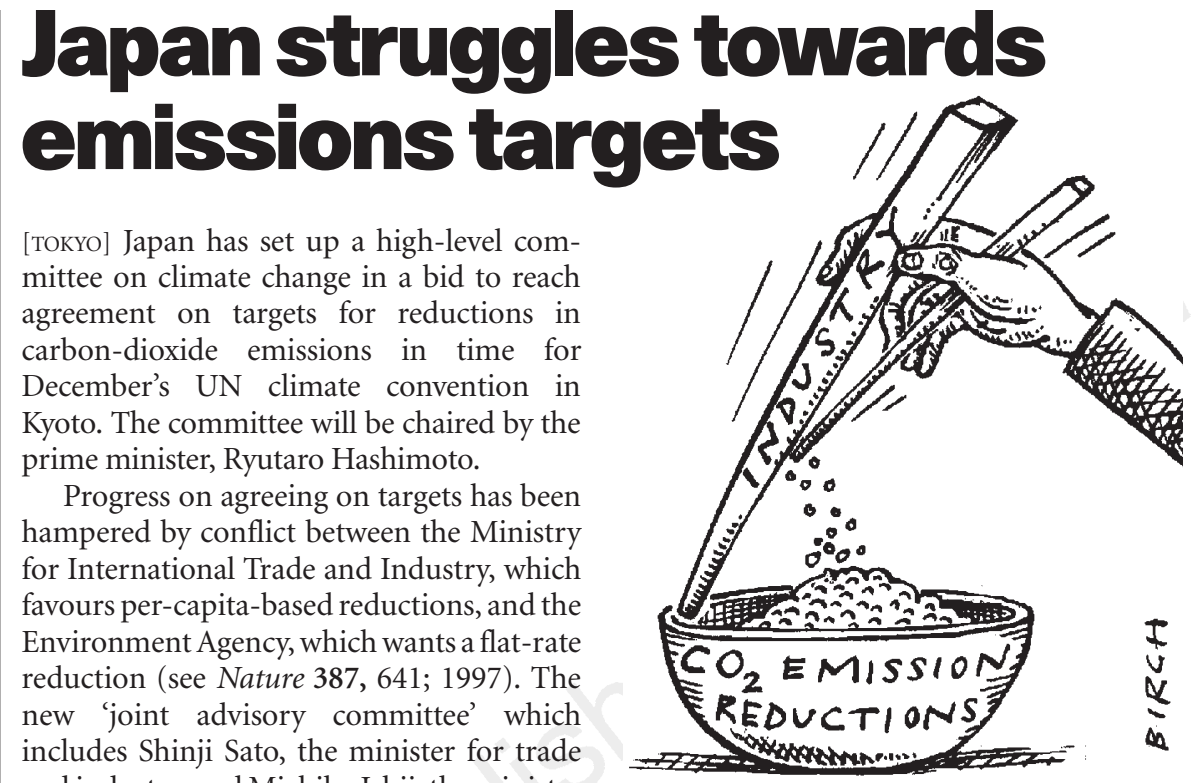
and industry, and Michiko Ishii, the minister of state of the Environmental Agency - is intended to get the two sides talking.

The committee is expected to recommend emission-reduction targets in time for the final preparatory meeting of the Kyoto conference in Bonn in October. According to press reports, Michiko Ishii announced last week that a "Japanese proposal for reduction targets should be above five per cent".

Environmental and consumer organizations complain, however, that industry interests are overrepresented on the committee. Citizen groups and nongovernmental organizations should also have been included, argues Setsuko Sumino of People's Forum 2001, a Japanese association of citizen groups. Critics are also unhappy that the committee's deliberations have not been made public.

In a related development, Diet members from the ruling coalition parties - the Liberal Democratic Party (LDP), Sakigake, and the Socialist Party — have also set up a discussion forum, chaired by the LDP politician Kazuo Aichi. The forum is to draft a consensus proposal on emission-reduction targets. Aichi is reported to have said that targets of up to ten per cent might be envisaged.

RobertTriendl

\section{'Slick' new company eyes medical diagnostics market}

[SAN FRANCISCO] Incyte Pharmaceuticals, Inc. and SmithKline Beecham (SKB) are to create a joint venture company called diaDexus to discover and commercialize molecular diagnostic products in a deal which brings together some of the newest technology in the area.

diaDexus will be based in Santa Clara, California, and will be owned equally by both parent companies. It will use bioinformatics and genomics initially to develop tests for disease detection, with particular emphasis on infectious diseases and oncology. The company also plans to create pharmacogenomic tests to optimize clinical drug testing and disease treatment according to the genetic differences between people.

Rachel Leheny, biotechnology industry analyst for the investment company Hambrecht \& Quist, Inc., calls the arrangement "slick". She says both companies bring significant technology and financial resources to the venture, and predicts that this should help to make diaDexus one of the three companies likely to dominate genomics-based diagnostics in the future. The other candidates, she predicts, are the California-based company Affymetrix, which is developing sophisticated DNA-chip technology, and the collaboration announced in July between Abbott Laboratories and the French company Genset to develop diagnostics for customizing pharmaceuticals for patient use.

Leheny says these companies were targeting a very lucrative segment of the future pharmaceutical business. Disease detection is their near-term goal, with pharmocogenomics "the holy grail", she said, adding that the deal underlines the sophistication of Incyte's genomics capabilities. "I think SmithKline saw that if they really needed to be competitive, they needed to get access to the best database," she said.

Incyte, which is based in Palo Alto, California, will provide diaDexus with nonexclusive access to its extensive human and microbial genomics databases. The new company will also have access to information from SKB's partners in genomics, including the Rockville,
Maryland-based company Human Genome Sciences, and to diagnostic data originating from SKB's own therapeutic research. Incyte and SKB said they would contribute a combined total of $\$ 25$ million to start the new company, which will have around 30 staff.

diaDexus plans initially to license proprietary diagnostic markers to diagnostic-kit manufacturers. The new company also will start business with five tests in late-stage-disease validation, including three for cancer and one for bone disease. Company officials said they hoped to introduce their first "homebrew" service laboratory test within two years, with diagnostic kits approved by the Food and Drug Administration ready within six years.

Dr George Poste, chief science and technology officer of SKB - which has its US headquarters in Philadelphia — will be chairman of the new company. John Burczak, director of research in molecular diagnostics at SKB, will become its research and development director. A chief executive will be hired early next year.

Sally Lehrman 